\title{
A Research on Application of Mobile Commerce in Logistics Industry
}

\author{
Gaoguang Li and Tingjie Lv
}

\begin{abstract}
School of Economics and Management, Beijing University of Posts and Telecommunications, Beijing 100876, P.R. China ligaoguang@gmail.com lutingiie@263.net
\end{abstract}

\begin{abstract}
The rapid development of mobile commerce (m-commerce) has profound influence on logistics industry. Firstly, through analysis that combines $\mathrm{m}$-commerce and the logistics industry, the paper draws a conclusion that main $\mathrm{m}$-commerce applications in logistics industry include cargo tracking, mobile inventory management, vehicle positioning and M2M (machine to machine) mobile services. Then, we think traditional logistics has entered the stage of electronic commerce logistics and is turning into the stage of m-commerce logistics gradually after analyzing relation between $\mathrm{m}$-commerce and logistics. As m-commerce logistics differs from traditional logistics, there is unique operation process of $\mathrm{m}$-commerce in logistics industry. Finally, from the perspective of value chain, the paper points out that there are three mobile commerce models including B2E (business to employee), B2B (business to business) and B2C (business to customer).
\end{abstract}

Keywords: Mobile commerce, Electronic commerce, Value chain, Logistics, Operation process, Mobile commerce mode

\section{INTRODUCTION}

Nowadays the rapid development of mobile commerce (m-commerce) has profound influence on logistics industry, m-commerce is based on the mobile communication network to conduct electronic commerce (e-commerce) activities via mobile communication terminals and equipment such as cell phone, PDA(personal digital assistance), notebook computer, etc. M-commerce can make enterprise complete any operation at any time and at any place, bring enterprise better service and efficiency. The applications of $m$-commerce in logistics industry will improve logistics enterprise's economic benefit, raise the level of logistics information and promote the transformation and upgrading of logistics industry. Starting the research in the area will be of practical significance in promoting the development of logistics industry, and it has an important theoretical value in promoting the development of the theory.

Although there have been a lot of studies on m-commerce and there have been a lot of studies on logistics industry, it is hard to find ones in which an integrated

Please use the following format when citing this chapter:

Li, G., Lv, T., 2007, in IFIP International Federation for Information Processing, Volume 255, Research and Practical Issues of Enterprise Information Systems Il Volume 2, eds. L. Xu, Tjoa A., Chaudhry S. (Boston: Springer), pp. 1091$1] 00$. 
perspective of mobile business based on logistics industry is suggested. This research develops application of $\mathrm{m}$-commerce in logistics industry.

The paper is organized as follows. In the next section, integrating characters of logistics industry, we sort out main applications related to logistics industry from a large deal of m-commerce applications, such as cargo tracking, mobile inventory management, vehicle positioning, M2M (machine to machine) mobile services. In the third section, we analyze the relation between $\mathrm{M}$-commerce and logistics industry, then construct the model of the M-commerce value chain of logistics enterprise; With modern communications technology and network technology applying in logistics industry, traditional logistics has entered the stage of e-commerce logistics, so the concept of m-commerce logistics is put forward, then the paper compares difference between traditional logistics and $\mathrm{m}$-commerce logistics. As m-commerce logistics differ from traditional logistics and the operation process of mobile commerce in logistics industry is unique, the paper depicts the operation process in detail. In succession, from the perspective of value chain, we think that there is three $\mathrm{m}$ commerce models including B2E (business to employee), B2B (business to business) and $\mathrm{B} 2 \mathrm{C}$ (business to customer). B2E model provides self-service platform for logistics enterprise's employee and saves enterprise's cost. B2B model enables company to achieve the strategy of Just-in-time (JT) production, it can reduce largely enterprise's inventory and expand the scope of enterprise cooperation; $\mathrm{B} 2 \mathrm{C}$ model shows mainly that logistics enterprise of applying m-commerce can obtain a good social effect through the provision of customer service and information. The final chapter is our discussion and outlook.

\section{MAIN APPLICATION OF MOBILE COMMERCE IN LOGISTICS INDUSTRY}

$\mathrm{M}$-commerce applications can range from as simple as an address book synchronization to as complicated as credit card transactions. There are potentially an unlimited number of $\mathrm{m}$-commerce applications $[1,2]$, many specialists have classified m-commerce applications from diverse perspective and based on different judgment standard. Varshney and Vetter developed a detailed class of m-commerce applications roughly categorized by m-commerce business models based on mobile characteristics [2]. The applications are classified into 11 categories, as shown in Table 1[2].

Basic functions of logistics system include packing, stowing, transport, storage, distribution processing, and logistics information management [3]. In addition to the basic functions, some value-added logistics services are also needed. Value-added logistics services involve following meanings: services increasing convenience (making persons lazy), services accelerating reaction velocity (making circulation process faster), services lowering cost (digging the third profit source), outspread services (integrating supply chain together). Through analyzing in depth the characteristics of logistics functions and combining classification of $\mathrm{m}$-commerce applications, we come up with the following four categories of m-commerce applications in logistics industry. 
Table 1. Classes of M-commerce Applications ([2], p.187)

\begin{tabular}{|l|l|}
\hline CLASS OF APPLICATIONS & \multicolumn{1}{|c|}{ EXAMPLES } \\
\hline Mobile financial applications & Banking, brokerage, and payments for mobile users \\
\hline Mobile advertising & User specific and location sensitive advertisements \\
\hline Mobile inventory management & Location tracking of goods, boxes, troops, and people \\
\hline Proactive service management & $\begin{array}{l}\text { Transmission of information related to aging } \\
\text { (automobile) components to vendors } \\
\text { Instant claim-payments by insurance companies }\end{array}$ \\
\hline Wireless reengineering & $\begin{array}{l}\text { Airlines competing to buy a landing time slot during } \\
\text { runway congestion }\end{array}$ \\
\hline Mobile auction or reverse auction \\
\hline $\begin{array}{l}\text { Mobile entertainment services \& } \\
\text { games }\end{array}$ & $\begin{array}{l}\text { Video-on-demand, audio-on demand, and interactive } \\
\text { games }\end{array}$ \\
\hline Mobile office & Working from traffic jams, airport, and conferences \\
\hline Mobile distance education & Taking a class using streaming audio and video \\
\hline Wireless data centre & $\begin{array}{l}\text { Detailed information on one or more products can be } \\
\text { downloaded by vendors }\end{array}$ \\
\hline Product locating and shopping & $\begin{array}{l}\text { Finding the location of a new/used car of certain model, } \\
\text { color and optional features }\end{array}$ \\
\hline
\end{tabular}

\subsection{Cargo Tracking}

Cargo tracking system refers to the approach of logistics transport enterprise obtaining timely information of freightage state (e.g., cargo variety and quantity, cargo condition in transit, delivery period, consignment site, consigner, consignee, cargo owner, delivery vehicles) and improving logistics transport services quality using EDI and bar code technology. When employees of logistics transport enterprise is in work process (i.e., collect cargo, stow in logistics center and deliver cargo to customer), they read or input logistics bar code information on cargo package and cargo invoice by mobile terminals, and then the information is sent to headquarter central computer by mobile communication network and intranet. After cargo information is processed, all carried cargo information is gathered in central computers. Cargo tracking system improves logistics services level effectively. Its specific functions are as follows:

- At the first, for customers, when customers need to inquire cargo state, they can know information of cargo state immediately as long as they input cargo invoice number to mobile terminals. Inquiring process is simply and rapid, information is timely and accurate.

- Second, for enterprise, enterprise can confirm whether cargo is sent to customers within the stipulated time or not. It can find immediately status that cargo isn't delivered to customer, and identify reason time in order to correct in time. Cargo tracking can improve the accuracy and timeliness of consignment and enhance customer service level.

- Finally, relative information of cargo transport state from cargo tracking system enriches sharing information of supply chain. The sharing information can inform customer preparing for receiving cargo and follow-up preparations. 


\subsection{Mobile Inventory Management}

Mobile inventory management (MIM) can achieve real-time input/inquire/update system database (e.g., storage, warehousing, inventory, transfer warehouse) in work site to the fullest extent, adopting wireless network technology and bar code technology. Thereby information is avoided secondary input by administrator.

MIM involves location tracking of goods, services. The tracking of goods may help service providers in determining the time of delivery to customer, thus improving customer service and obtaining a competitive edge over other businesses. One very interesting application is "rolling inventory"- which may involve multiple trucks carrying a large amount of inventory while on the move. Whenever a store needs certain items/goods, it can locate a truck (preferably in nearby area) and just-in-time delivery of goods can be performed. The rolling inventory and delivery application can reduce the amount of inventory space and cost for both vendors and stores and may also reduce the time between when an order is placed and the goods are delivered. Using inexpensive embedded radio/microwave devices (chips), a wireless network can track goods and services. Since satellite signals may not work well inside a truck, a separate wireless LAN can be provided on-board for intra truck communication and tracking. Another example of MIM is just-in-time delivery/movement of components in an assembly plant based on the rate of consumption of existing components. A variety of new components can be moved a certain speed after receiving a wireless signal from the components reaching the assembly line or from a device on the assembly line itself. This will allow just-in-time delivery leading to a reduced inventory and assembling cost. If the new components are delayed for some reason, then signals can be sent to the assembly line for possible adjustment of the assembly speed to match the arrival time of new components. Such an application would reduce the inventory cost while increasing productivity by matching the speed of new component arrival to the rate of assembly. For implementation purposes, location tracking of components can be broken into two components: indoor and outdoor. Indoor tracking can be performed by a chipset and location information may be transmitted over a satellite or cellular/PCS system to the component supplier where such information is needed [1].

\subsection{M2M (Machine to Machine) Mobile Services}

M2M mobile services involves communications between machines/equipments, $\mathrm{M} 2 \mathrm{M}$ mobile services in logistics enterprise include goods (property)security business, surveillance on automotive equipment, automatic meter measurement and data acquisition, equipment maintenance, vending-machine condition monitoring, various public facilities flow monitoring, motorcade management automation, distance information processing, etc.

- Inventory state monitoring: It can achieve distance control, know inventory condition and respond in time to alarm.

- Motorcade and fleet management: It can achieve motorcade management or fleet tracking through mobile device installed motorcade and fleet. Travel through the 
installation of mobile equipment vessels management, or the tracking of and management.

- Security operations: installing mobile sensors in various valuables, the valuables can be safely tracked at any time.

- Mobile POS (point of sales): Mobile POS Machine can achieve acceptance of cargo payment, which has safe/convenient feature.

\subsection{Vehicle Positioning}

According to the requirement of logistics enterprises constructing flexible wireless dispatching system, GPRS network system can be used to achieve two-way information transmission between logistics enterprises dispatching centre and transport vehicles. Dispatching centre links mainframe of logistics enterprise dispatching centre using GPRS terminal through mobile GPRS network. Currently, mobile positioning in logistics industry include following items.

- Vehicle anti-robbery and anti-theft. Comparing to currently several other antitheft systems, the system adopted by mobile positioning services has prominent benefits which include small system volume and light weight. It can be placed at any position of vehicle and isn't easy to be found by motor vehicle theft. This anti-theft system achieves indoor/outdoor orientation without blocking effect. Comparing with GPS (Global position system), its cost is lower, for example, if cell phone is used to positioning terminal, terminal price can keep under 1000 RMB. Furthermore, safe operation of positioning system can be independently monitored completely by relevant department.

- Dispatching management of group motorcade, personnel and leasehold equipment. In many cases, managers of group motorcade/personnel need to schedule timely owned vehicles/personnel in order to reduce no-load and improve efficiency. Managers hope the vehicles/personnel being the shortest distance apart from customer can arrive at location of customer in the shortest possible time. Depending on mobile positioning services, managers can know the position of vehicles/personnel at any moment in order that they dispatch vehicles/personnel rapidly according to customer demand at any moment. Comparing with GPS, positioning technology adopt by mobile positioning is characterized as manager's identifying location expediently and dispatching management even if vehicles/personnel enter covering and building inner.

- Location Based Service (LBS). These services utilize a user's location to pro vide location-content including information on restaurants, devices, users, and products [4]. When vehicle/personnel at unfamiliar areas want to know how to reach destination, they can obtain location information needed from mobile terminal screen just a few seconds later. 


\section{M-COMMERCE OPERATION PROCESS IN LOGISTICS INDUSTRY}

Formerly, person's understanding toward m-commerce concept often just stays in the perceived level of mobile paperless trade. They think they are able to achieve $m$-commerce operation process, so long as there are abundant/developed business resources and adequate financial strength. So many online dealers still believe $\mathrm{m}$ commerce is completed as long as they establish connection between online catalog and parcels in shopping cart and receive order from customers.

In fact, receiving order is only the beginning of m-commerce, a lot of work is happened in other processing (i.e., payment processing, order implementation, product delivery, product returns).M-commerce is a revolution in high-tech and information technology, it makes physical processing (e.g., advertisement, business, order, purchase, payment, authentication) virtual, makes it divorce from entities and is able to deal with information in computer networks. It makes information processing by electronic equipment, strengthens information processing and weakens entity processing. Some experts point out that the development of $\mathrm{m}$-commerce must enhance the development of logistics industry. Not only logistics enterprise is the warehouse of manufacturing enterprises, but also it is user's physical product suppliers. Logistics enterprises become only the most concentrated and extensive physical supplier representing all manufacturing enterprises and supplying dealer, logistics industry become the leader and coordinator of social production chain and provide comprehensive logistics services for community.

M-commerce has changed commodity sales model, and hence drives traditional logistics to undergo a fundamental change. Forrester Research summarizes main differences between $\mathrm{m}$-commerce logistics and traditional logistics [5], as shown in table 2.

Table 2. Traditional Logistics VS M-commerce Logistics

\begin{tabular}{l|l|l}
\hline Customer & \multicolumn{1}{|c|}{$\begin{array}{c}\text { TRADITIONAL } \\
\text { LOGISTICS }\end{array}$} & M-COMMERCE LOGISTICS \\
\hline Inventory & Strategy (pertinence) & $\begin{array}{l}\text { Unknown (all mobile user, } \\
\text { latent) }\end{array}$ \\
\hline Demand mode & Single side (seller) & Two sides (seller and buyer) \\
\hline Stowage mode & $\begin{array}{l}\text { Pull (passivity) } \\
\text { Bulk (according to cargo } \\
\text { type) }\end{array}$ & $\begin{array}{l}\text { Push (go-aheadism) } \\
\text { Parcel (according to specific } \\
\text { order) }\end{array}$ \\
\hline $\begin{array}{l}\text { Average transaction } \\
\text { sum }\end{array}$ & $\begin{array}{l}\text { Enormous } \\
\text { (wholesale) }\end{array}$ & Small sum (retail) \\
\hline Destination cargo & Convergence (dealer) & Decentralization (customer) \\
\hline $\begin{array}{l}\text { Supplying } \\
\text { demand }\end{array}$ & Steady/ consistent & Discontinuous/seasonal \\
\hline $\begin{array}{l}\text { Commodity } \\
\text { responsibility }\end{array}$ & Single tache & All supply chain \\
\hline
\end{tabular}

Clearly, these differences can help us to learn about the future developing direction and models of m-commerce logistics, it also the base of observing logistics 
change. But how does m-commerce operate under modern logistics support. Above all, we need to understand $\mathrm{m}$-commerce operation process, as shown in figure 1.

As shown on following figure, from the outset of the transaction, the flow of product/services from one customer to another customer forms a chain-like link which is what we call the supply chain. The chain effect is that transferring product and service in accordance with the principle of JIT, it is very important to implement effective warehouse management and distribution management. But some dealers think that ultimate realization of m-commerce can complete via replacing by traditional business method and there isn't need building m-commerce logistics system over again. To the extent, this attitude leads to human ignoring the fulfilling process of $\mathrm{m}$-commerce. However, in reality, on B2B (business to business) $\mathrm{m}$ commerce, vender attention has advanced the new realm (namely, service sale) from product sale. In m-commerce operation process, logistics serves directly the end customer, so service level determines customer satisfaction and decides whether $\mathrm{m}$ commerce operation is smooth. This means the enterprises that can provide better quality compound service and own considerable cost advantage have a stronger competition advantage. So applying $\mathrm{m}$-commerce and following $\mathrm{m}$-commerce operation process will improve largely enterprise competition advantage.

\section{M-COMMERCE MODEL IN LOGISTICS INDUSTRY}

Logistics enterprises obtain value by providing high-quality services customer, staffs in logistics enterprises obtain value through subordinating management and offering human and material resources to enterprises. M-commerce providers acquire affordable value by providing all kinds of $\mathrm{m}$-commerce applications and helping logistics enterprise to strengthen transport management. The logistics enterprise $\mathrm{m}$ commerce value chain is depicted as figure 2 . In the entire value chain, there are three models of $\mathrm{m}$-commerce applications.

\subsection{B2E (Business to Employee) M-commerce Model}

B2E m-commerce model is used mainly in logistics enterprises internal management and office application, its purpose is to enhance their management level in virtue of best available mobile management tools. B2E model asks all internal staffs own mobile terminal (e.g., cell phone, PDA), so B2E m-commerce applications have extensive using base, it can be used in depth to office applications and business operation. If all kinds of operation management in logistics enterprise integrate deeply $\mathrm{m}$-commerce application, $\mathrm{m}$-commerce will play an important role in B2E application of logistics enterprise.

Through establishing mobile office system in logistics enterprise, mobile inquiries all preparative work from OA system can be implemented. The staffs can search and view notice/e-mail/information in enterprise website, and they are able to receive various work order and logistics scheduling. They may feedback immediately task completion state; they also develop various mobile office system as short message application platform to achieve dispatching order issue. At the same time, 
aiming at logistics enterprise scattered warehouse and dangerous goods storage, they can develop logistics storage wireless data transmission and wireless monitoring alarm system to implement warehouse effective management.

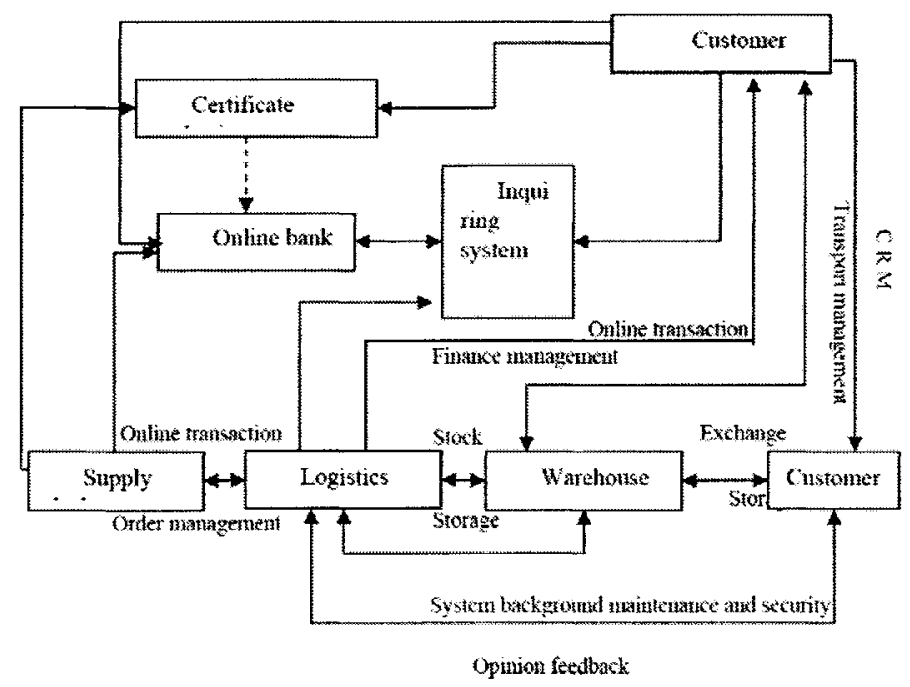

Figure 1. Logistic Enterprise M-commerce Operation Process

$B 2 E$ value reflects the following aspects.

- Providing enterprise staffs self-service platform; helping them self-study and self-improvement.

- Self-service can save directly enterprise cost. It can reduce auxiliary staffs and save payout of some business activities (e.g., stock, welfare, partners, customer call center, and relation management).

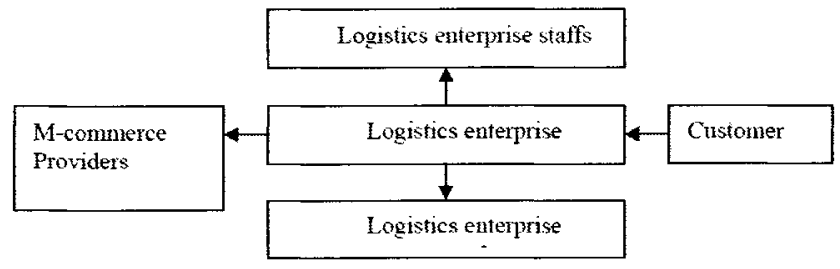

Figure 2. Logistics Enterprise M-commerce Value Chain

\subsection{B2B (Business to Business) M-commerce Model}

B2B m-commerce model is largely reflected that logistics enterprises construct vehicle monitoring and control system based on the operator's GSM/ GPRS network, 
and the overall solution includes VPMN cross VPMN, broadband Internet access, Global Link address book and wireless DDN (SMS GPRS vehicle monitoring scheduling). SMS/GPRS vehicle monitoring system can conduct real-time logistics enterprises vehicles and understands position/ state of the vehicle, the state can be displayed electronic map in controlling center, that make dispatching staffs arrange vehicles and personnel easily. The specific applications are showed as follows.

- Electronic map. High-quality maps can be flexible to customize landmark, freely zoom and smoothly move.

- Visual scheduling. It can real-time carry cargo accurately and schedule vehicles; it can track the state of every itinerary and order implementing, and update itinerary information automatically.

- Vehicles status tracking record. It includes following contents: tracking vehicle location by satellite positioning, historical record of vehicle trips, corresponding cargo status information (arrival, stowage, leaving, wait, rest, discharge), Vehicle dynamic information (parking, stowage, rest), truck/trailer situation, drivers and driving conditions, traffic conditions.

- Emergency feedback. It includes untoward incidents, traffic accidents, natural disasters alarm;

- Matching terminal equipment. For example, they can manage mobile inventory using bar code scanner.

\subsection{B2C (Business to Customer) M-commerce Model}

B2C m-commerce model is largely reflected that logistics enterprises provide customer service information to obtain better social effect by virtue of $\mathrm{m}$-commerce applications.

Specific applications are as follows.

- SMS of logistics information or WAP (wireless application protocol) inquires.

- Electronic order of logistics demand (phone mail).

- Bulletin of logistics information (SMS delivering extensively).

- Automatic e-mail report (informing customer of freight information timely).

- Freight BBS (mobile chat).

\section{DISCUSSION AND OUTLOOK}

The development of logistics management generally goes through three stages, namely traditional storage and transportation stage, System optimization stage, information stage. The application of information technology is the important symbol of logistics information. The stage of logistics information can divide into two periods: e-commerce logistics, m-commerce logistics. With intense competition and improving demand of customer, logistics industry needs advanced technology to make logistics system smart.

Meanwhile, with rapid development of mobile communications technology and network technology and rapid popularity of mobile terminal/device, the condition of $\mathrm{m}$-commerce application matures gradually, and application scope is wider and wider. 
It has profound influence on all kinds of industry including logistics industry. Modern logistics is turning the stage of e-commerce logistics into $\mathrm{m}$-commerce logistics. However, since $\mathrm{m}$-commerce is still in the developing stage, there are a series of problems: technology juvenility not unified technical standards, safety problem hidden danger, privacy protection, etc. such problems will affect $\mathrm{m}$ commerce in logistics industry. Merely, the government and enterprises have attached importance to $\mathrm{m}$-commerce gradually, and they started to make some measures to guide m-commerce healthy development. Hence, in near future, the applied scope of $\mathrm{m}$-commerce in logistics industry become wider, it will lead logistics information to depth.

\section{REFERENCES}

1. G. Xu and J.A. Gutiérrez, An Exploratory Study of Killer Applications and Critical Success Factors in M-Commerce, Journal of Electronic Commerce in Organizations. Volume 4, Number 3, pp.63-79, (2006).

2. U. Varshney and R. Ventter, Mobile Commerce: Framework, Applications and Networking Supporting, Mobile Networks and Applications. Volume 1, Number 7, pp.185-198, (2002).

3. W. Zhang, Y. Tian, and Z. Lin, Logistics Management in Electronic Commerce Northern Jiao Tong University Press: Beijing, 2003).

4. U. Varshney, Location Management for Mobile Commerce Applications in Wireless Internet Environment, ACM Transactions on Internet Technology. Volume 3, Number 3, pp.236-255, (2003).

5. Z. Wang, S. Gao, and F. Hu, Logistic Development Strategies in E-Commerce, Journal of Zhanjiang Normal College. Volume 26, Number 1, pp.81-84, (2005). 